\title{
Analisa Kepuasan Konsumen Menggunakan Klasifikasi Decision Tree Di Restoran Dapur Solo (Cabang Kediri)
}

\author{
Ahmad Shiddiq ${ }^{1}$, Ratih Kumalasari Niswatin ${ }^{2}$, Intan Nur Farida ${ }^{3}$ \\ 1,2, ${ }^{3}$ Teknik Informatika, Fakultas Teknik, Universitas Nusantara PGRI Kediri \\ E-mail:*1t tdc2606@gmail.com, ${ }^{2}$ ratih.workmail@gmail.com, ${ }^{3}$ in.nfarida@ gmail.com
}

\begin{abstract}
Abstrak - Kepuasan konsumen merupakan tingkat dimana anggapan terhadap produk sesuai dengan harapan para konsumen. Harapan konsumen umumnya merupakan prakiraan atau keyakinan konsumen tentang apa yang akan diterimanya bila telah membeli atau mengkonsumsi suatu produk. Kenyataannya, apa yang bisa memuaskan konsumen di satu situasi mungkin tidak bisa memuaskan konsumen yang sama di lain situasi. Ditambah dengan sistem keluhan konsumen yang hanya disediakan contact person oleh pihak restoran. Dengan demikian, kepuasan konsumen sangat sulit diketahui, karena tidak semua konsumen menghubungi contact person yang disediakan. Maka dari itu, adanya penelitian mengenai analisis kepuasan konsumen di Restoran Dapur Solo (Cabang Kediri) tersebut diperlukan. Untuk memenuhi kebutuhan-kebutuhan diatas, banyak cara yang dapat ditempuh. Salah satunya adalah dengan melakukan pemanfaatan data perusahaan yang diolah dengan klasifikasi Decision Tree menggunakan algoritma C4.5. Dari proses klasifikasi akan menghasilkan beberapa aturan yang menyebabkan konsumen merasa puas dan tidak puas, serta seberapa besar konsumen merasa puas maupun tidak puas.
\end{abstract}

Kata Kunci — konsumen, produk, contact person, decision tree, algoritma C4.5.

Abstract - Consumer satisfaction is the level where the assumption of the product in accordance with the expectations of consumers. Consumer expectations are generally consumer forecasts or beliefs about what they will receive when buying or consuming a product. In fact, what can satisfy consumers in one situation may not be able to satisfy the same consumer in another situation. Coupled with a consumer complaints system that only provided contact person by the restaurant. Thus, consumer satisfaction is very difficult to know, because not all consumers contact the contact person provided. Therefore, the existence of research on the analysis of customer satisfaction in Restaurant Dapur Solo (Kediri Branch) is required. To meet the needs above, many ways that can be taken. One of them is by utilizing company data that is processed by Decision Tree classification using C4.5 algorithm. From the classification process will produce some rules that cause consumers to feel satisfied and not satisfied, and how much consumers are satisfied or not satisfied.

Keywords - satisfaction, product, contact person, decision tree, C4.5 algoritm.

\section{PENDAHULUAN}

Dalam dunia bisnis yang selalu dinamis dan penuh persaingan, para pelakunya harus selalu memikirkan cara-cara untuk terus survive dan jika mungkin dapat mengembangkan skala bisnisnya. Ditambah persaingan dalam bidang makanan minuman sangat berkembang pesat seiring dengan bertambahnya inovasi dan kreasi baru para pebisnis. Oleh karena itu para pebisnis banyak melakukan cara atau strategi yang lebih baik agar dapat memenuhi kebutuhan konsumen serta memberikan kepuasan secara maksimal dan melayani dengan sebaiknya. Karena tujuan dari suatu bisnis adalah untuk menciptakan rasa puas kepada konsumen. Salah satu tindakan yang harus dilakukan untuk meraih keunggulan bersaing tersebut adalah fokus terhadap konsumen dengan memberikan sebuah pengalaman yang dapat memberikan kepuasan bagi konsumen. 
Kepuasan konsumen merupakan tingkat dimana anggapan terhadap produk sesuai dengan harapan para konsumen. Harapan konsumen umumnya merupakan prakiraan atau keyakinan konsumen tentang apa yang akan diterimanya bila telah membeli atau mengkonsumsi suatu produk. Seorang konsumen mungkin mengalami berbagai tingkat kepuasan, yaitu bila produk tidak sesuai dengan harapannya setelah dikonsumsi, maka konsumen tersebut akan merasa tidak puas. Namun bila terjadi sebaliknya yaitu produk sesuai dengan harapannya, maka konsumen akan merasa puas sehingga suatu saat akan mengkonsumsi kembali produk tersebut.

Konsumen yang puas adalah konsumen yang akan berbagi kepuasan dengan produsen. Bahkan, konsumen yang puas akan berbagi rasa dan pengalaman dengan konsumen lain. Oleh karena itu, baik konsumen maupun produsen akan sama-sama diuntungkan apabila kepuasan terjadi. Kenyataannya, apa yang bisa memuaskan konsumen di satu situasi mungkin tidak bisa memuaskan konsumen yang sama di lain situasi. Ditambah dengan sistem keluhan konsumen yang hanya disediakan contact person oleh pihak restoran. Dengan demikian, kepuasan konsumen sangat sulit diketahui, karena tidak semua konsumen menghubungi contact person yang disediakan. Maka dari itu, adanya penelitian mengenai analisis kepuasan konsumen di Restoran Dapur Solo (Cabang Kediri) tersebut diperlukan.

Pihak manajer pemasaran restoran mengharapkan adanya teknologi yang mampu menghasilkan suatu informasi yang siap digunakan untuk membantu menentukan langkah strategis yang harus diambil. Manajer juga ingin mengetahui sejauh mana kepuasan konsumen dan bidang apa yang perlu ditingkatkan untuk mencapai kepuasan dari para konsumennya. Untuk memenuhi kebutuhan-kebutuhan diatas, banyak cara yang dapat ditempuh. Salah satunya adalah dengan melakukan pemanfaatan data perusahaan (Data Mining) dengan klasifikasi Decision Tree menggunakan algoritma C4.5. Dari proses klasifikasi akan menghasilkan beberapa rule atau aturan yang menyebabkan konsumen merasa puas dan tidak puas, serta seberapa besar konsumen merasa puas maupun tidak puas.

Restoran Dapur Solo merupakan salah satu perusahaan yang bergerak dibidang bisnis penjualan dengan produk utama makanan dan minuman. Dimana perusahaan ini setiap harinya harus memenuhi kebutuhan konsumen dan dituntut untuk dapat memberikan kepuasan bagi setiap konsumennya. Untuk dapat melakukan hal tersebut, perusahaan membutuhkan sumber informasi yang cukup banyak agar dapat dianalisis lebih lanjut. Pada Restoran Dapur Solo, terdapat beberapa permasalahan yang kerap muncul mengenai kepuasan konsumen. Perusahaan sulit mendapatkan informasi-informasi mengenai tingkat kepuasan konsumen yang telah berkunjung. Karena sebab itu, penulis membuat penelitian dengan judul "Analisa Kepuasan Konsumen Melalui Pendekatan Klasifikasi Decision Tree di Restoran Dapur Solo (Cabang Kediri)".

Menurut Han \& Kamber (2006), decisson tree adalah sebuah diagram alir yang mirip dengan struktur pohon, dimana setiap internal node menotasikan atribut yang diuji, setiap cabangnya mepresentasikan hasil dari atribut tes tersebut dan leaf node mepresentasikan kelas-kelas tertentu atau distribusi dari kelas-kelas. Istilah Decision Tree adalah proses menemukan kumpulan pola atau fungsi-fungsi yang mendeskripsikan dan memisahkan kelas data satu dengan lainnya, untuk dapat digunakan untuk memprediksi data yang belum memiliki kelas data tertentu [1].

Menurut Han (2006), pengertian algoritma C4.5 merupakan salah satu algoritma yang digunakan untuk membangun pohon keputusan yang berbasis algoritma induksi pohon keputusan seperti ID3, Hunt dan CART. Keempat algoritma tersebut pada dasarnya memiliki karakteristik yang sama dalam membangun pohon keputusan, yaitu top-down dan divide-and-conquer. Topdown artinya pohon keputusan dibangun dari simpul akar ke daun, sementara divide-and-conquer artinya data latih secara rekursif dipartisi ke dalam bagian-bagian yang lebih kecil saat pembangunan pohon [1]. berikut [2]:

Secara umum Algoritma C4.5 langkah untuk membangun pohon keputusan adalah sebagai

a. Pilih atribut sebagai akar.

b. Buat cabang untuk masing-masing nilai.

c. Bagi kasus dalam cabang.

d. Ulangi proses untuk masing-masing cabang sampai semua kasus pada cabang memiliki kelas yang sama.

Untuk memilih atribut sebagai akar, didasarkan pada nilai gain tertinggi dari atribut-atribut yang ada. Untuk menghitung gain digunakan rumus seperti yang tertera berikut:

$$
\operatorname{Gain}(S, A)=\operatorname{Entropy}(S)-\sum_{i=1}^{n} \frac{\left|S_{i}\right|}{|S|} * \operatorname{Entropy}\left(S_{i}\right) \text {. }
$$




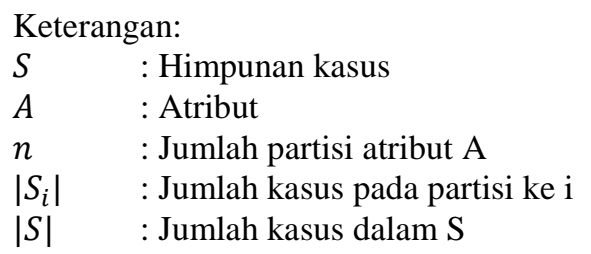

Sebelum mendapatkan nilai Gain adalah dengan mencari nilai Entropi. Entropi digunakan untuk menentukan seberapa informatif sebuah masukan atribut untuk menghasilkan sebuah atribut. Rumus dasar dari Entropi adalah sebagai berikut:

$$
\operatorname{Entropy}(S, A)=-\sum_{i=1}^{n} p_{i} * \log _{2} p_{i}
$$

Keterangan:

$\begin{array}{ll}S & : \text { Himpunan Kasus } \\ A & : \text { Fitur } \\ n & : \text { Jumlah partisi S } \\ P_{i} & \text { : Proporsi dari Si terhadap S }\end{array}$

Beberapa penelitian yang mendasari dilakukannya penelitian ini adalah Penelitian yang dilakukan Eka Budi Rahayu pada tahun (2015) yang berjudul "Algoritma C4.5 Untuk Penjurusan Siswa SMA Negeri 3 Pati”, penelitian ini bertujuan agar kelak dikemudian hari, pelajaran yang diberikan kepada siswa lebih terarah. Karena tidak jarang juga siswa-siswi yang asal-asalan dalam menentukan jurusan yang mereka ambil. Berdasarkan permasalahan tersebut, maka dilakukan penelitian untuk mengklasifikasi data penjurusan siswa berdasarkan atribut yang sudah ditentukan oleh pihak sekolah SMA Negeri 3 Pati. Metode yang digunakan dalam klasifikasi adalah metode pengklasifikasian dengan menggunakan Decission Tree (Pohon Keputusan) dengan salah satu algoritma yang digunakan adalah C4.5. Sehingga nantinya dapat digunakan sebagai dasar pertimbangan dalam menentukan proses penjurusan. Eksperimen dan evaluasi dengan menggunakan 239 data set dan dibagi untuk data training 70\%, data testing 30\% [3].

Penelitian yang dilakukan Mochamad Rizki Ilham S pada tahun (2015) yang berjudul "Implementasi Data Mining Menggunakan Algoritma C4.5 Untuk Prediksi Kepuasan Pelanggan Taksi Kosti”. Penelitian ini bertujuan untuk menganalisis kepuasan pelanggan Taksi KOSTI dengan menggunakan teknik data mining dengan algoritma C4.5. Atribut masukan kepuasan pelanggan dalam penelitian ini mencangkup harga, fasilitas, pelayanan dan loyalitas. Dalam penelitian ini, didapatkan bahwa hasil yang didapatkan berasal dari beberapa atribut masukan menghasilkan hubungan sebab-akibat dalam mengklasifikasikan konsumen puas dan tidak puas. Penelitian ini diharapkan dapat membantu pihak KOSTI dalam meningkatkan kepuasan konsumen untuk mempertahankan pelanggan dan meningkatkan laba perusahaan taksi KOSTI tersebut [4].

Penelitian yang dilakukan Ratih Kumalasari Niswatin dan Resty Wulanningrum (2017) berjudul "Penerapan Algoritma Decision Tree pada Penentuan Keberhasilan Akademik Mahasiswa”. Sistem prediksi prestasi mahasiswa berdasarkan latarbelakang pendidikan yang menggunakan metode decision tree dilakukan pada mahasiswa Program Studi TeknikInformatika Fakultas Teknik Universitas NusantaraPGRI Kediri. Tujuan dari pembuatan sistem ini adalahuntuk membantu proses penerimaan mahasiswa barudalam melakukan seleksi calon mahasiswa berdasarkanhasil prediksi prestasi mahasiswa dan membantu pihakjurusan untuk mengelompokkan mahasiswa baruberdasarkan latar belakang pendidikannya. Metodeyang digunakan untuk memprediksi prestasi mahasiswaadalah metode decision tree algoritma C4.5 denganmenggunakan beberapa kriteria berdasarkan latarbelakang pendidikan mahasiswasebelumnyadiantaranya nilai UANMatematika, nilai UAN Bahasa Indonesia, nilai UANBahasa Inggris, jurusan di sekolah asal, dan rata-rata raport di sekolah asal [5].

\section{METODE PENELITIAN}

Metode yang digunakan untuk pengembangan sistem yang akan dibuat menggunakan konsep waterfall. Berikut ini merupakan tahapan-tahapan dari metode penelitian yang akan dilakukan. 


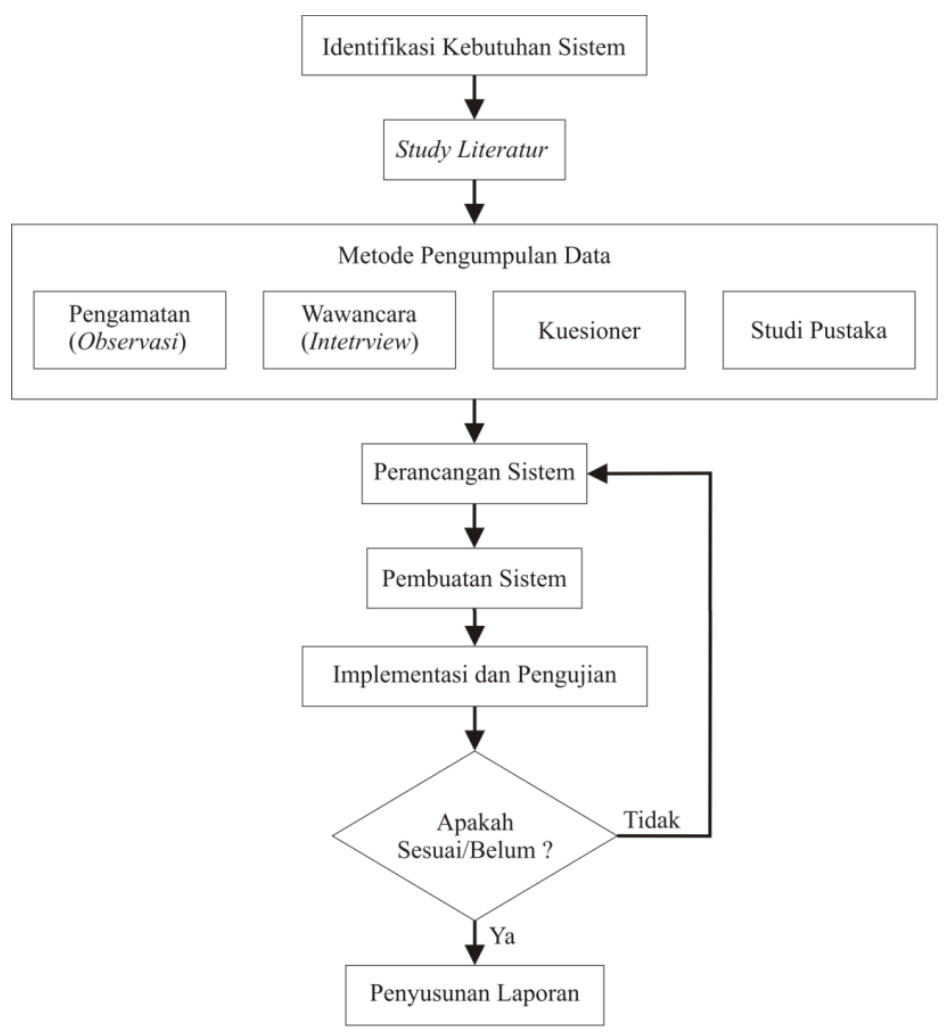

Gambar 1.1 Tahapan Metode Penelitian

Gambar 1.1 merupakan tahapan-tahapan metode penilitan yang secara garis besar akan dijabarkan sebagai berikut :

a. Identifikasi Kebutuhan Sistem

Pada tahap awal penelitian, dilakukan identifikasi mengenai kebutuhan serta masalah-masalah yang perlu diselesaikan. Serta pengumpulan informasi yang dapat dijadikan sebagai bahan untuk membuat aplikasi. Tahap ini dilakukan pendekatan dalam penelitian secara kualitatif yang digunakan untuk meneliti pada kondisi objek yang alamiah dimana konsumen merasa puas atau tidak puas.

b. Study Literatur

Tahap ini adalah tahap pembelajaran konsep tentang pengolahan data menggunakan sistem terkomputerisasi berbasis dekstop. Dalam pemahaman serta penjelasan konsep ini didapat baik dari buku-buku referensi, jurnal penelitian, paper, artikel yang di dapat dari internet, ataupun sistem aplikasi yang sudah pernah di buat sebelumnya.

c. Metode pengumpulan data

Metode pengumpulan data yang penulis lakukan di dalam penelitian ini adalah:

1) Pengamatan (Observasi)

Pada tahap ini kegiatan yang dilakukan adalah pengumpulan data yang dilakukan dengan pengamatan secara langsung pada obyek penelitian di Restoran Dapur Solo (Cabang Kediri).

2) Wawancara (Intervieuw)

Pada tahap ini kegiatan yang dilakukan adalah pengumpulan data dengan cara mengadakan tanya jawab secara langsung dari sumber informasi terkait objek yang diteliti yaitu Manager/pemilik dan konsumen Restoran Dapur Solo (Cabang Kediri).

3) Kuesioner

Pada tahap ini, peneliti mengumpulkan data dengan cara memberikan seperangkat pertanyaan atau pernyataan tertulis kepada konsumenuntuk dijawab yaitu tingkat dimana konsumen merasa puas tidak puas. 
d. Perancangan Sistem

Perancangan sistem pada penelitian ini berdasarkan dari hasil studi pustaka, survei dan observasi, yang kemudian di tuangkan menjadi alur program serta menentukan algoritma yang cocok untuk penelitian ini.

e. Pembuatan Sistem

Pada tahap ini, peneliti mulai membuat sistem yang direncanakan berdasarkan hasil perancangan sistem yang telah dilakukan sebelumnya kedalam bentuk dalam bentuk Data Flow Diagram (DFD), Entity Relationship Diagram (ERD) dan Flowchart. Selanjutnya dengan menggunakan aplikasi Borland Delphi 7.0 yang menggunakan bahasa pascal akan membuat desain antar muka dan pengodean. Desain antar muka yang dimaksud merupakan tindak lanjut penerapan rancangan desain antar muka yang telah dibuat pada tahapan perncangan sistem. Sedangkan pengodean adalaah penerapan hasil rancangan ke dalam bentuk yang dapat dibaca dan dimengerti oleh komputer.

f. Implementasi dan pengujian

Setelah tahap pembuatan sistem telah selesai, maka dilakukan pengujian atas sistem tersebut. Sehingga dapat diketahui bagaimana jalannya sistem dan melakukan perbaikan-perbaikan jika ditemui kesalahan. Pengujian difokuskan pada aktifitas pemastian bahwa semua perintah yang ada telah di jalankan dan fungsi eksternal untuk memastikan bahwa dengan masukan tertentu suatu fungsi akan menghasilkan keluaran sesuai dengan yang dikehendaki.

g. Penyusunan Laporan.

Penyusunan laporan di lakukan setelah kegiatan selesai dikerjakan. Laporan disusun berdasarkan data yang diperoleh, survei dan observasi, pembelajaran materi, perancangan dan pembuatan sistem, serta implementasi dan pengujian.

\section{HASIL DAN PEMBAHASAN}

Pembahasan terhadap hasil penelitian dan pengujian yang diperoleh disajikan dalam bentuk uraian teoritik, baik secara kualitatif maupun kuantitatif. Hasil percobaan sebaiknya ditampilkan dalam berupa grafik atau pun tabel. Untuk grafik dapat mengikuti format untuk diagram dan gambar.

Simulasi perhitungan klasifikasi kepuasan konsumen Restoran Dapur Solo (Cabang Kediri) dengan algoritma $\mathrm{C} 4.5$ yang menggunakan 15 data kuesioner sebagai data training.

Tabel 1. Data Training Makanan

\begin{tabular}{|c|c|c|c|c|c|c|c|c|c|c|c|}
\hline $\begin{array}{l}\text { Sign- } \\
\text { board }\end{array}$ & $\begin{array}{c}\text { Ekste- } \\
\text { rior }\end{array}$ & $\begin{array}{l}\text { Tempat } \\
\text { Nyaman }\end{array}$ & $\begin{array}{c}\text { Keber- } \\
\text { sihan }\end{array}$ & Parkir & Lokasi & Layout & $\begin{array}{c}\text { Rasa } \\
\text { Maka- } \\
\text { nan }\end{array}$ & $\begin{array}{c}\text { Rasa } \\
\text { Minu- } \\
\text { man }\end{array}$ & Staf & Harga & $\begin{array}{l}\text { Klasi- } \\
\text { fikasi }\end{array}$ \\
\hline $\mathrm{Ya}$ & Menarik & Baik & $\mathrm{Ya}$ & $\mathrm{Ya}$ & $\mathrm{Ya}$ & Menarik & Enak & Enak & Ramah & $\mathrm{Ya}$ & Puas \\
\hline $\mathrm{Ya}$ & Menarik & Baik & $\mathrm{Ya}$ & $\mathrm{Ya}$ & $\mathrm{Ya}$ & Menarik & Enak & Enak & Kurang & $\mathrm{Ya}$ & Puas \\
\hline $\mathrm{Ya}$ & Menarik & Baik & $\mathrm{Ya}$ & $\mathrm{Ya}$ & $\mathrm{Ya}$ & Menarik & Enak & Enak & Ramah & $\mathrm{Ya}$ & Puas \\
\hline $\mathrm{Ya}$ & $\begin{array}{c}\text { Tidak } \\
\text { menarik }\end{array}$ & Baik & $\mathrm{Ya}$ & $\mathrm{Ya}$ & $\mathrm{Ya}$ & Lumayan & Lumayan & Lumayan & Ramah & Kurang & Puas \\
\hline $\mathrm{Ya}$ & Menarik & Tidak & $\mathrm{Ya}$ & $\mathrm{Ya}$ & $\mathrm{Ya}$ & Lumayan & Lumayan & Lumayan & Kurang & Kurang & $\begin{array}{l}\text { Tidak } \\
\text { puas }\end{array}$ \\
\hline $\mathrm{Ya}$ & $\begin{array}{c}\text { Tidak } \\
\text { menarik }\end{array}$ & Baik & $\mathrm{Ya}$ & Tidak & $\mathrm{Ya}$ & $\begin{array}{c}\text { Tidak } \\
\text { menarik }\end{array}$ & $\begin{array}{c}\text { Tidak } \\
\text { Menarik }\end{array}$ & $\begin{array}{c}\text { Tidak } \\
\text { Menarik }\end{array}$ & Lumayan & $\begin{array}{c}\text { Tidak } \\
\text { Menarik }\end{array}$ & $\begin{array}{l}\text { Tidak } \\
\text { puas }\end{array}$ \\
\hline Tidak & $\begin{array}{c}\text { Tidak } \\
\text { menarik }\end{array}$ & Baik & Ya & Tidak & $\mathrm{Ya}$ & $\begin{array}{c}\text { Tidak } \\
\text { menarik }\end{array}$ & $\begin{array}{c}\text { Tidak } \\
\text { Menarik }\end{array}$ & $\begin{array}{c}\text { Tidak } \\
\text { Menarik }\end{array}$ & Ramah & $\begin{array}{c}\text { Tidak } \\
\text { Menarik }\end{array}$ & Puas \\
\hline $\mathrm{Ya}$ & Menarik & Baik & $\mathrm{Ya}$ & Tidak & Tidak & Lumayan & Lumayan & Lumayan & Lumayan & $\mathrm{Ya}$ & Puas \\
\hline Tidak & $\begin{array}{c}\text { Tidak } \\
\text { menarik }\end{array}$ & Tidak & $\mathrm{Ya}$ & Tidak & $\mathrm{Ya}$ & Lumayan & Lumayan & Kurang & Kurang & Tidak & $\begin{array}{l}\text { Tidak } \\
\text { puas }\end{array}$ \\
\hline $\mathrm{Ya}$ & $\begin{array}{c}\text { Tidak } \\
\text { menarik }\end{array}$ & Tidak & $\mathrm{Ya}$ & Tidak & $\mathrm{Ya}$ & Menarik & Lumayan & Lumayan & Kurang & Lumayan & Puas \\
\hline $\mathrm{Ya}$ & Menarik & Baik & Tidak & $\mathrm{Ya}$ & $\mathrm{Ya}$ & $\begin{array}{c}\text { Tidak } \\
\text { menarik }\end{array}$ & $\begin{array}{c}\text { Tidak } \\
\text { Menarik }\end{array}$ & $\begin{array}{c}\text { Tidak } \\
\text { Menarik }\end{array}$ & Lumayan & $\begin{array}{c}\text { Tidak } \\
\text { Menarik }\end{array}$ & $\begin{array}{l}\text { Tidak } \\
\text { puas }\end{array}$ \\
\hline $\mathrm{Ya}$ & Menarik & Baik & Tidak & $\mathrm{Ya}$ & $\mathrm{Ya}$ & $\begin{array}{c}\text { Tidak } \\
\text { menarik }\end{array}$ & $\begin{array}{c}\text { Tidak } \\
\text { Menarik }\end{array}$ & $\begin{array}{c}\text { Tidak } \\
\text { Menarik }\end{array}$ & Ramah & $\begin{array}{c}\text { Tidak } \\
\text { Menarik }\end{array}$ & Puas \\
\hline $\mathrm{Ya}$ & Menarik & Baik & $\mathrm{Ya}$ & $\mathrm{Ya}$ & Tidak & Menarik & Lumayan & Lumayan & Lumayan & Lumayan & Puas \\
\hline $\mathrm{Ya}$ & Menarik & Baik & $\mathrm{Ya}$ & $\mathrm{Ya}$ & $\mathrm{Ya}$ & Lumayan & Enak & Lumayan & Ramah & Lumayan & Puas \\
\hline $\mathrm{Ya}$ & Menarik & Baik & $\mathrm{Ya}$ & $\mathrm{Ya}$ & $\mathrm{Ya}$ & $\begin{array}{c}\text { Tidak } \\
\text { menarik }\end{array}$ & Lumayan & Lumayan & Ramah & Lumayan & Puas \\
\hline
\end{tabular}

Selanjutnya data kuesioner di sederhanakan menjadi tiga kategori yaitu produk, fasilitas dan pelayanan agar pengklasifikasiannya lebih sederhana seperti terlihat pada tabel 2 . 
Tabel 2. Penyederhanaan Data Kuesioner

\begin{tabular}{|l|l|l|l|}
\hline Produk & Fasilitas & Pelayanan & Klasifikasi \\
\hline Baik & Ya & Ramah & Puas \\
\hline Baik & Ya & Kurang & Puas \\
\hline Baik & Ya & Ramah & Puas \\
\hline Lumayan & Ya & Ramah & Puas \\
\hline Lumayan & Ya & Kurang & Tidak puas \\
\hline Kurang & Ya & Lumayan & Tidak puas \\
\hline Kurang & Ya & Ramah & Puas \\
\hline Baik & Ya & Lumayan & Puas \\
\hline Lumayan & Ya & Kurang & Tidak puas \\
\hline Baik & Ya & Kurang & Puas \\
\hline Kurang & Ya & Lumayan & Tidak puas \\
\hline Kurang & Ya & Ramah & Puas \\
\hline Baik & Ya & Lumayan & Puas \\
\hline Baik & Ya & Ramah & Puas \\
\hline Lumayan & Ya & Ramah & Puas \\
\hline
\end{tabular}

Setelah dianalisis dataset memiliki 15 kasus yang terdiri 11 "PUAS" dan 4 "TIDAK PUAS" pada kolom klasifikasi (lihat tabel 2). Selanjutnya menghitung entropy dengan menggunakan rumus pada persamaan (2).

$$
\text { Jadi entropy }(S)=\left(-\left(\frac{11}{15}\right) \times \log _{2}\left(\frac{11}{15}\right)\right)+\left(-\left(\frac{4}{15}\right) \times \log _{2}\left(\frac{4}{15}\right)\right)=0,83664074
$$

Tabel 3 Hasil Perhitungan Dataset

\begin{tabular}{|c|c|c|c|}
\hline Total kasus & Sum(Puas) & Sum(Tidak Puas) & Entropi total \\
\hline 15 & 11 & 4 & 0,83664074 \\
\hline
\end{tabular}

Setelah mendapat entropi dari keseluruhan kasus, lakukan analisis pada pada setiap atribut dan nilai-nilainya serta hitung juga entropinya, seperti terlihat pada tabel 4 .

Tabel 4. Analisis Atribut, Nilai, Banyaknya Kejadian Nilai, Entropi dan Gain

\begin{tabular}{|c|c|c|c|c|c|c|c|}
\hline $\begin{array}{l}\text { No- } \\
\text { de }\end{array}$ & Atribut & Nilai & $\begin{array}{c}\text { Sum } \\
\text { (Nilai) }\end{array}$ & $\underset{\text { (Puas) }}{\text { Sum }}$ & $\begin{array}{l}\text { Sum } \\
\text { (Tidak } \\
\text { Puas) }\end{array}$ & Entropi & Gain \\
\hline \multirow[t]{11}{*}{1} & \multirow[t]{4}{*}{ Product } & Baik & 7 & 7 & 0 & 0 & \\
\hline & & Lumayan & 4 & 2 & 2 & 1 & \\
\hline & & Kurang & 4 & 2 & 2 & 1 & \\
\hline & & & & & & & 0.30330741 \\
\hline & \multirow[t]{3}{*}{ Fasilitas } & $\mathrm{Ya}$ & 15 & 11 & 4 & 0,83664074 & \\
\hline & & Tidak & 0 & 0 & 0 & 0 & \\
\hline & & & & & & & 0 \\
\hline & \multirow[t]{4}{*}{ pelayanan } & Ramah & 7 & 7 & 0 & 0 & \\
\hline & & Lumayan & 4 & 2 & 2 & 1 & \\
\hline & & Kurang & 4 & 2 & 2 & 1 & \\
\hline & & & & & & & 0.30330741 \\
\hline
\end{tabular}

Untuk menghitung gain setiap atribut menggunakan rumus pada persamaan (1).

Jadi :

$\operatorname{Gain}(\operatorname{Product})=0,83664074-\left(\left(\frac{7}{15}\right) \times 0+\left(\frac{4}{15}\right) \times 1+\left(\frac{4}{15}\right) \times 1\right)$

$\operatorname{Gain}($ Product $)=0.30330741$

Hitung pula gain dari atribut yang lain. Karena nilai gain terbesar adalah Gain (Proudct) dan Gain (Pelayanan), maka ambil yang leih awal yaitu Gain (Product). Setelah itu maka product menjadi node akar (root node). Lihat tabel 4 yang memiliki cell berwarna kuning.Kemudian pada 
productbaik memiliki 7 kasus yang memiliki jawaban puas. Dengan demikian product baik menjadi daun atau leaf. Lihat tabel 4 yang memiliki sel berwarna hijau.

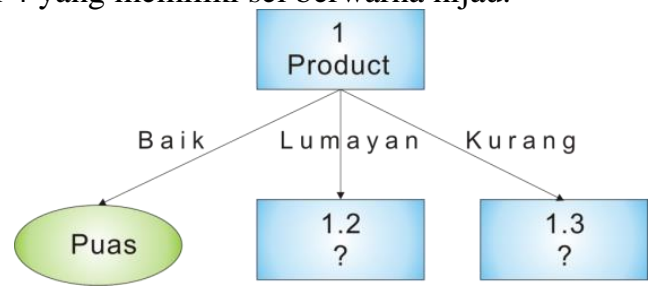

Gambar 2. Pohon Keputusan Node 1 (root node)

Berdasarkan pembentukan pohon keputusan node 1 (root node), Node 1.2 dan node 1.3 akan dianalisis lebih lanjut, namun akan terlebih dahulu diproses node 1.2. Untuk mempermudah, tabel 5.2 difilter, dengan data yang memiliki Product = Lumayan sehingga jadilah tabel 5.

Tabel 5. Data Yang Memiliki Product Lumayan

\begin{tabular}{|c|c|c|c|}
\hline Produk & Fasilitas & Pelayanan & Klasifikasi \\
\hline Lumayan & Ya & Ramah & Puas \\
\hline Lumayan & Ya & Kurang & Tidak puas \\
\hline Lumayan & Ya & Kurang & Tidak puas \\
\hline Lumayan & Ya & Ramah & Puas \\
\hline
\end{tabular}

Kemudian data pada tabel 5 dianalisis dan dihitung lagi entropi atribut product lumayan dan entropi setiap atribut serta gainnya dengan mengecualikan atribut product yang sudah berada pada jalur pohon diatasnya, sehingga hasilnya seperti pada tabel 6 Setelah itu tentukan pilih atribut yang memiliki gain tertinggi untuk dibuat node berikutnya.

Tabel 6. Hasil Analisis Node 1.2

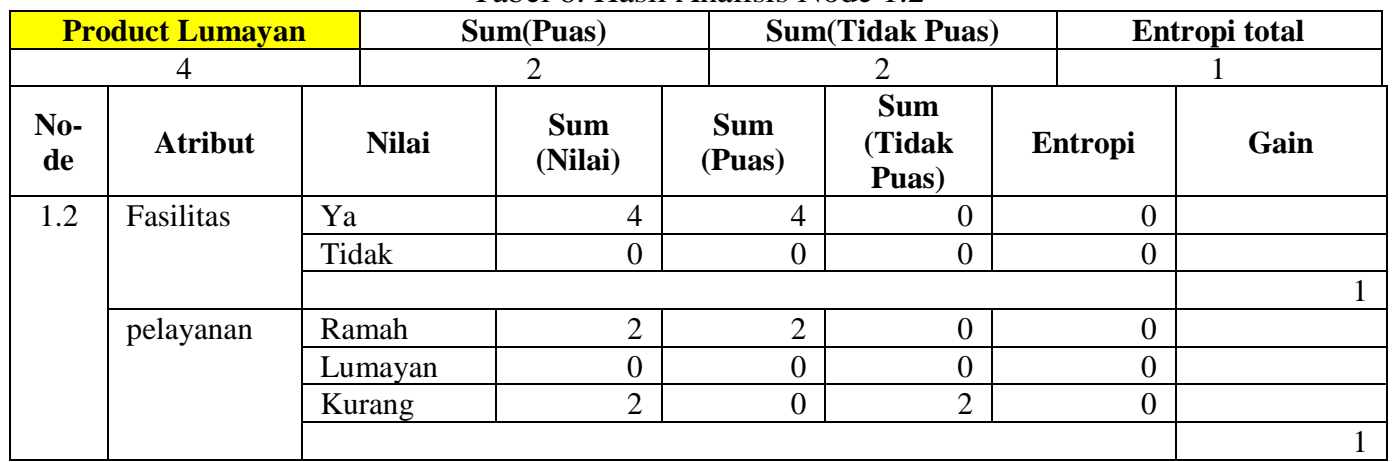

Karena gain keduanya memiliki nilai yang sama maka dipilih yang awal yaitu fasilitas. Sehingga node selanjutnya yaitu fasilitas ya dengan klasifikasi puas.

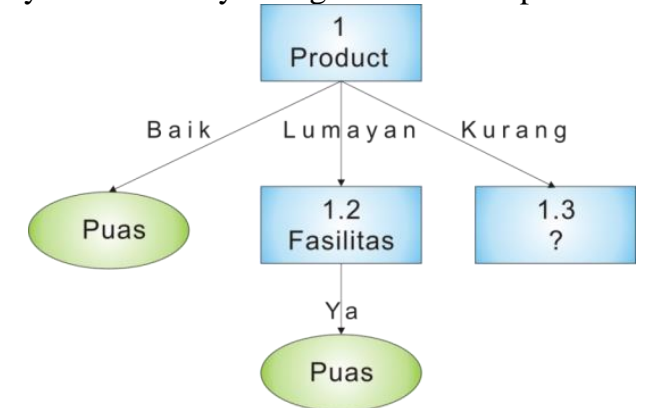

Gambar 3. Pohon Keputusan Analisis Node 1.2

Karena node 1.2 sudah menemukan ujung dari setiap cabangnya, maka node 1.2 sudah bisa dikatakan selesai. Untuk selanjutnya maka menganilisis node 1.3 menggunakan data pada tabel 5.2 
yang difilter dengan ketentuan product $=$ kurang seperti terlihat pada tabel 7 dan kemudian dihitung lagi seperti langkah sebelumnya maka hasilnya ditampilkan pada tabel 8 dan gambar 4.

Tabel 7. Data Yang Memiliki Rasa Minuman Lumayan

\begin{tabular}{|c|c|c|c|}
\hline Produk & Fasilitas & Pelayanan & Klasifikasi \\
\hline Kurang & Ya & Lumayan & Tidak puas \\
\hline Kurang & Ya & Ramah & Puas \\
\hline Kurang & Ya & Lumayan & Tidak puas \\
\hline Kurang & Ya & Ramah & Puas \\
\hline
\end{tabular}

Tabel 8. Hasil Analisis Node 1.3

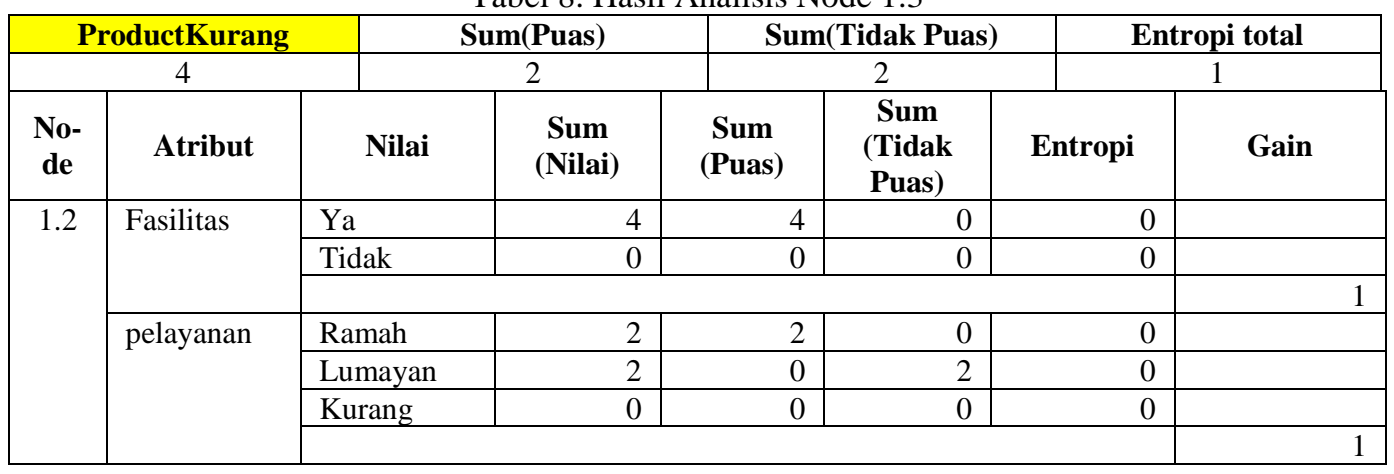

Karena gain keduanya memiliki nilai yang sama maka dipilih yang awal yaitu fasilitas. Sehingga node selanjutnya yaitu fasilitas ya dengan klasifikasi puas.

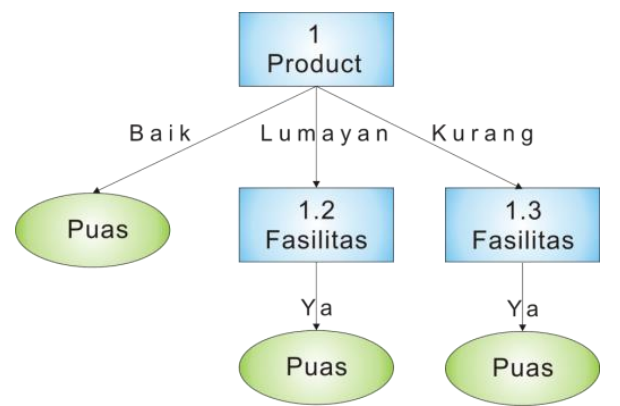

Gambar 4. Pohon Keputusan Analisis Node 1.3

Setelah semua node selesai maka rule dari pohon keputusan tersebut disimpan di database pada tabel dataset_hasil. Selanjutnya untuk testing akan menambahkan data baru dan selanjutnya akan dibandingkan dengan rule yang telah ada dan selanjutnya data akan disimpan di database pada tabel dataset_training. Hasil akhir akan menampilkan rule yang berada pada tabel dataset_hasil dan dipilah antara klasifikasi puas dan tidak puas. Klasifikasi puas akan menampilkan rule penyebab kenapa konsumen merasa puas. Sedangkan untuk klasifikasi tidak puas akan menampilkan rule kenapa konsumen merasa tidak puas.

Pada gambar 4 berikut ini merupakan data flow diagram system. 


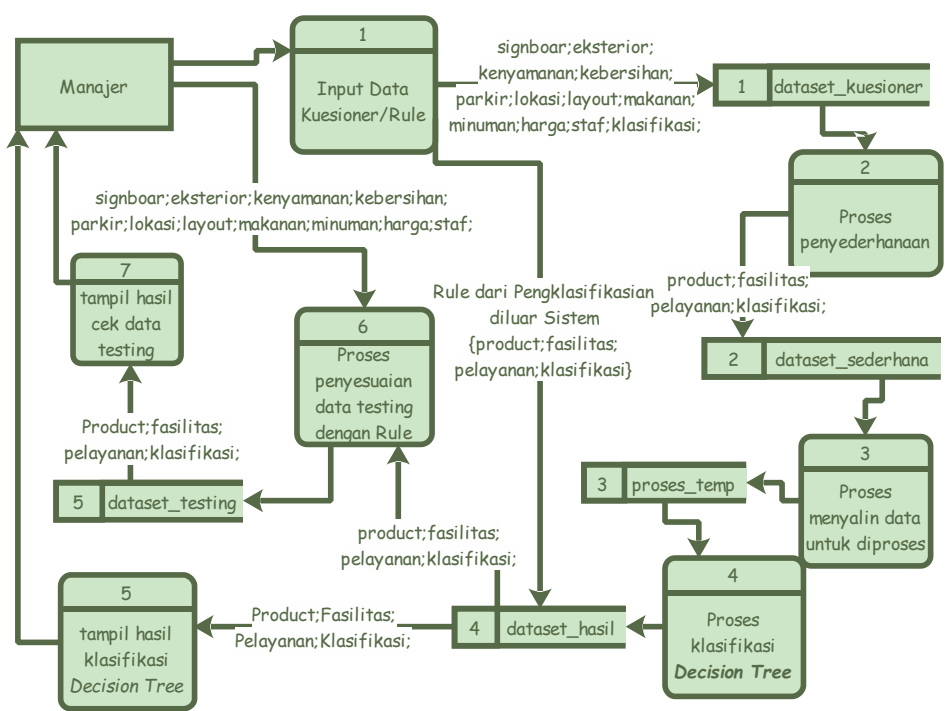

Gambar 5. Data Flow Diagram

Gambar 5 menunjukan desain DFD level 1 yang merupakan penjabaran dari DFD level 0. Pada DFD level 1 menunjukan perincian dari setiap proses seperti proses login manajer/user, input ke database, dan penyimpanan hasil dari proses klasifikasi. Manajer dapat memasukkan data kuesioner yang kemudian disederhanakan terlebih dahulu kedalam 3 kategori. Setelah itu data disalin ke tabel sementara untuk dilakukan proses klasifikasi decision tree yang hasilnya akan disimpan didalam database dan dapat dilihat langsung oleh manajer. Manajer juga dapat memasukkan rule dari proses decision tree diluar sistem. Manajer dapat pula melakukan testing dengan memasukkan data yang kemudian akan dibandingkan dengan data rule yang telah terdapat didalam sistem. Gambar 6 berikut ini menunjukkan hasil klasifikasi pada sistem.

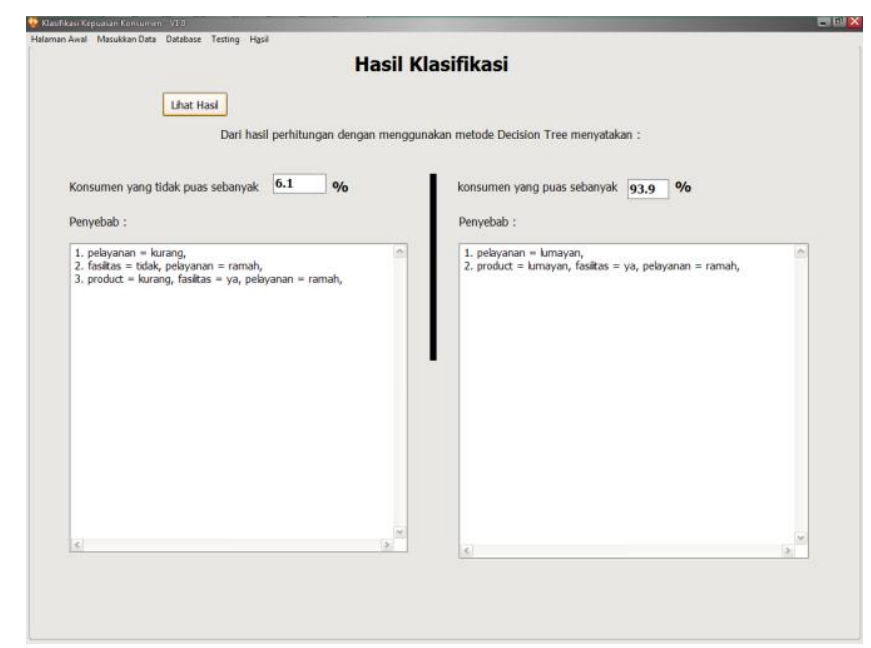

Gambar 6. Halaman Hasil Klasifikasi

Gambar 6 merupakan tampilan halaman hasil. Pada halaman ini akan diperlihatkan hasil dari klasifikasi yaitu rule dimana konsumen merasa puas maupun tidak puas. Yaitu dengan menampilkan penyebab kenapa konsumen merasa puas dan tidak puas serta persentase dari keduanya.

\section{SIMPULAN}

Dari hasil dan pembahasan penelitian yang telah dilakukan dapat disimpulkan bahwa berdasarkan dari 300 record data yang digunakan dapat disimpulkan bahwa : 
1. Sistem ini dapat mengklasifikasikan konsumen merasa tidak puas apabila pelayanan dirasa kurang, fasilitas dirasa kurang dan pelayanan ramah, product dirasa kurang, fasilitas dirasa baik dan pelayanan dirasa ramah.

2. Sistem ini dapat mengklasifikasikan konsumen merasa puas apabila pelayanan dirasa lumayan, product dirasa lumayan, fasilitas dirasa baik dan pelayanan dirasa ramah.

\section{DAFTAR PUSTAKA}

[1]. Han, J. \& Kamber, M. 2006. Data Mining Concept and Tehniques. San Fransisco: Morgan Kauffman.

[2]. Andayani, S. 2007. Pembentukan Cluster dalam Knowledge Discovery in Database dengan Algoritma K_Means. Jurnal SemnasIF, (Online), tersedia : http://staff.uny.ac.id, diunduh 26 Juni 2017.

[3]. Rahayu, E.B. 2015. Algoritma C4.5 untuk Penjurusan Siswa SMA Negri 3 Pati. Skripsi. Semarang: Jurusan Teknik Informatika, Fakultas Ilmu Komputer, Universitas Dian Nuswantoro Semarang.

[4]. Ilham, S.M.R. \& Purwanto. 2015. Implementasi Data Mining Menggunakan Algoritma C4.5 untuk Prediksi Kepuasan Pelanggan Taksi Kosti. Tesis. Semarang: Jurusan Teknik Informatika, Fakultas Ilmu Komputer, Universitas Dian Nuswantoro Semarang.

[5]. Niswatin, R.K. \& Wulanningrum, R. 2017. Penerapan Algoritma Decision Tree pada Penentuan Keberhasilan Akademik Mahasiswa. Makalah disajikan dalam Seminar Nasional Teknologi Informatika dan Multimedia 2017. STMIK AMIKOM Yogyakarta, 4 Februari 2017. 